\title{
EAl Endorsed Transactions

\section{A Comprehensive Study on Highly Sensitive Photonics Based Acoustic Sensors for Under Water Applications}

Hareesh $\operatorname{Kumar}^{1, *}$ and M. N Sreerangaraju ${ }^{2}$

\author{
${ }^{1}$ Research scholar, VTU-Belagavi, BIT Research Centre, Dept. of ECE, Bangalore Institute of technology, \\ Bengaluru 560004, India \\ 2 Professor, Dept. of ECE, Bangalore Institute of technology, Bengaluru 560004, India
}

\begin{abstract}
By referring few researcher works which is related to the work of optical sensor and able to detect the acoustic signal, this review paper provides the detailed study of acoustic signal in under water. Researchers has worked with the optical sensor and emerged as great promising sensing device. From various research papers it is observed that the detection of acoustic signal is done with the help of various optical sensors. The various sensors are fiber bragg grating (FBG) sensor, fiber optic interferometric sensor and Mach zehnder interferometer (MZI) sensor. So this review paper covers all these sensors and their application with a particular focus on the different structure of optical sensor. The structure of the various sensors and their application is discussed from the different research paper.

The overall work is reported and corresponding result is demonstrated. From the demonstrated work it has been observed that with good quality and proper sensitivity in all optical sensors are able to detect the acoustic signal for under water due to their compact size and able to provide accurate results.
\end{abstract}

Keywords: Optical Fiber Acoustic Sensing, Mach Zehnder Interferometer, fiber optic interferometric sensor, piezo electric sensor, fiber bragg grating (FBG) sensor, Photonic crystal fiber (PCF)

Received on 10 March 2020, accepted on 25 May 2020, published on 10 June 2020

Copyright (C) 2020 Hareesh Kumar et al., licensed to EAI. This is an open access article distributed under the terms of the Creative Commons Attribution licence (http://creativecommons.org/licenses/by/3.0/), which permits unlimited use, distribution and reproduction in any medium so long as the original work is properly cited.

doi: 10.4108/eai.13-7-2018.165235

${ }^{*}$ Corresponding author. Email:hareevlsi@gmail.com

\section{Introduction}

The OFAS (optical fiber acoustic sensing) system is popular to monitor the acoustic wave which is generated by the external sources. Acoustic wave is kind of mechanical wave which is very important to carrying the information. With different frequency band the detected acoustic wave can be applicable for various fields such as

ultrasonic medicine, underwater acoustic monitoring and aerospace.

Since few decades the development in acoustic sensing domain, this optical sensing devices has been observed and provides the detailed information. The advantage of this optical sensor is anti-electromagnetic interference and less loss for long distance transmission. Due to their high sensitivity, compact size, these sensors are applied in different field of applications. 
Another most important and popular sensor is Mach Zehnder Interferometer. It was demonstrated as temperature sensor and pressure sensor. The mechanism of this mach Zehnder interferometer is that it uses laser source as source. This light beam will be decoupled by the two arms and recoupled at the receiver end. Because of its high sensitivity MZI can be used as acoustic sensor. When sensing arm of MZI is conveying the acoustic signal and include a change in optical path and then introducing phase shift at receiver end.

Ian F. Akyildiz et.al has worked with sensors which has potential to unexplored application and to enhance ability to observe and predict the ocean. So authors worked with sensors, which are related to network and gathered information about under water environment. In this paper they worked with underwater acoustic sensors which constitute a basis from Shengye HUANG discussion of the challenges associated with the underwater environment. Tao Fu et.al, they worked with different sensor such as two dimensional sensor networks, three dimensional sensor network.[1]. Problem can be observed from this paper in approaching of different network layer under water is difficult.

Geoffrey A et. al. focused on work of detection of acoustic signal under water using Fiber-Optic Interferometric Sensors. This sensor is electro ceramic transducers. Xiaohong Bai et.al, the authors discussed about this sensor array. Work has been done by a hydrophones installed named as the fiber-optic bottom mounted array, which is large and time division multiplexed architecture.

In military sonar and seismic survey system this sensor can be used [2]. The designed hydrophone is used to get consistent with the good acoustic resolution but it should be specified depth. There should be proper frequency response with the operating frequency range of interest.

The mechanical properties of the materials and the geometry of the design factors which can influence the above design matter. The design of hydrophone is very important and design should be such that mechanical properties of the material frequency are higher than operating frequency. So choosing of material is crucial part to demonstrate this kind sensor. So another approach can be proposed to detect the acoustic signal in under water are Photonic crystal sensor, fiber bragg grating sensor or mach Zehnder interferometer can be proposed for the experiment.

Shengye HUANG. et. al [3] worked with optical fiber hydrophone which responds with temperature compensation package and able to provide improved sensitivity with a frequency from $2.5 \mathrm{kHz}$ to $12 \mathrm{kHz}$. This acoustic sensor is one kind of transducer which is able to convert pressure into elastic vibration as shown in resultant output.

Graham Wild et. al. has done experiment with Fiber Bragg Grating (FBG) sensors to detect the acoustic signal. There are numerous advantages of FBG sensor so it can be useful for detecting of acoustic signal in under water.
Authors observed the advantages of FBG and have done experiment on FBG sensor.

The merits of FBG as sensing elements, which can be either, stress or temperature. In this work we also showcase recent outputs.

Optical fiber grating have been immerged in optical platform to detect chemical and bio chemical elements as sensor. By inducing this interaction in the transmission spectrum along the fibers so there will be change in the measurement of refractive index.

There will be combination of optical fibers, Based on this approach the optical fiber gratings are considered because of its advantages and limitations [5].

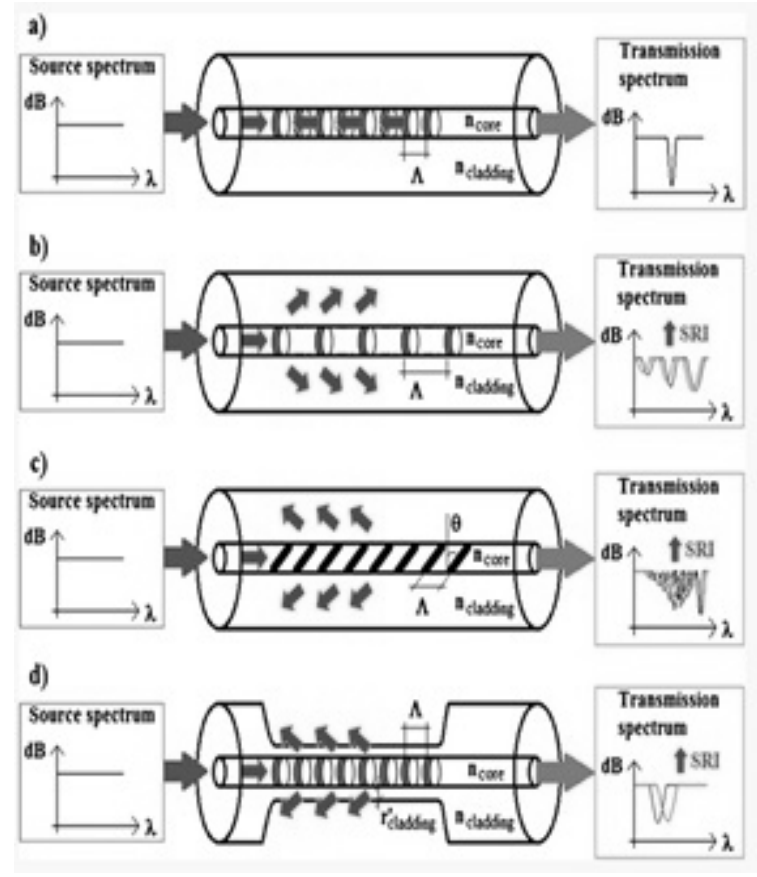

Figure 1. Basic configuration of optical fiber gratings a) Standard FBG b) Standard long period Grating c) Tilted FBG d) Etched FBG

Another way to approach the FBG sensor is to detect the DNA sequence. FBG is inscribed and the inner surface of a microstructure fiber has been functionalized by covalent linking of a peptide nuclei acid probe targeting a DNA sequence bearing a single point mutation implication in crystal fibrosis disease.

The essential part of new, fast and lowest price technology for healthcare, medical platform and detection of any chemical and organic, inorganic substances.

Sensor which is used to detect of bimolecular in an aqueous solution. Many researchers have put effort to implement a sensor for bio-applications. Fluorophorelabeled DNA is inserted in the air holes of the microstructure part of a PCF. In the presence of the target 
bimolecular, the transmission peak located in the fluorophore revealed [5].

For a many applications in various areas optical fiber gratings have developed including physical sensing for temperature, strain, acoustic waves and pressure.

The fiber bragg grating is etched as the sensing element by a narrow bandwidth [6].Optical refract metric type biosensor (ORTB) based on the FBG to determine the octane number of gasoline.

For a number of sensing applications, Fiber grating sensors are of significant. But this fiber bragg grating (FBG) sensor can used to detect acoustic signal in under water. Hill et al. in 1978 demonstrated the optical fiber bragg grating (FBG)[9]. Meltz et al developed this method which is called as transverse holographic fabrication method. After that, FBG has become very much popular.

There is a very important advantage of optical Fiber Sensors compare to other sensors that is small in size, good quality sensitivity and immunity to EMI. The advantage of this FBG is sensitive to a number of measured while being multiplexed. By discussing about application of FBG acoustic sensor, many researchers worked on the FBG and represent the detection.

Kavya V. Ullal, et al. In this paper authors explores the movement of the micro optical elements, which manipulates the light passes through all the dimensional spaces for micro opted-electro mechanical systems (MOEMS). These are used to detect stress, strain and other mechanical parameters based on the displacement using photonic crystal sensors for detection of acoustic signals[8].

T. Zouache et al, In this work the two-dimensional photonic crystal waveguide coupled to a point-defect resonant micro cavity. The resonant wavelength will shift when pressure variation induces change in the refractive indexes of the structure and these sensors have compactness, high sensitivity, and various choices of materials[28].

\section{Review of Literature}

Table 1. Comparison of different types of optical sensors

\begin{tabular}{|c|c|c|c|c|}
\hline $\begin{array}{l}\text { Classifi } \\
\text { cation }\end{array}$ & $\begin{array}{l}\text { Advant } \\
\text { ages }\end{array}$ & $\begin{array}{l}\text { Disadvanta } \\
\text { ges }\end{array}$ & $\begin{array}{l}\text { Challeng } \\
\text { es }\end{array}$ & $\begin{array}{l}\text { Applicati } \\
\text { ons }\end{array}$ \\
\hline $\begin{array}{l}\text { Signal } \\
\text { proces } \\
\text { sing } \\
\text { metho } \\
\text { d }\end{array}$ & $\begin{array}{l}\text { Rejectin } \\
\text { g noise } \\
\text { and } \\
\text { interfere } \\
\text { nce, } \\
\text { improve } \\
\text { s snr }\end{array}$ & $\begin{array}{l}\text { It will reduce } \\
\text { computation } \\
\text { al } \\
\text { requirement, } \\
\text { restrict the } \\
\text { frequency } \\
\text { band }\end{array}$ & $\begin{array}{l}\text { Shifting } \\
\text { and } \\
\text { isolates } \\
\text { the signal } \\
\text { frequenc } \\
\text { y band to } \\
\text { be } \\
\text { centered } \\
\text { at zero } \\
\text { frequenc }\end{array}$ & $\begin{array}{l}\text { It is used } \\
\text { for } \\
\text { exploiting } \\
\text { of all the } \\
\text { known } \\
\text { characteris } \\
\text { tics of the } \\
\text { signal like } \\
\text { dimension } \\
\text { of time, }\end{array}$ \\
\hline
\end{tabular}

\begin{tabular}{|c|c|c|c|c|}
\hline & & & $y$ & $\begin{array}{l}\text { frequency } \\
\text { and space }\end{array}$ \\
\hline $\begin{array}{l}\text { Highly } \\
\text { sensiti } \\
\text { vity } \\
\text { therma } \\
\text { lly } \\
\text { stable } \\
\text { acousti } \\
\text { c fiber } \\
\text { sensor }\end{array}$ & $\begin{array}{l}\text { High } \\
\text { sensitivi } \\
\text { ty }\end{array}$ & $\begin{array}{l}\text { Bandwidth } \\
\text { relaxes the } \\
\text { constraint on } \\
\text { sensors } \\
\text { operating } \\
\text { wavelength }\end{array}$ & $\begin{array}{l}\text { Light } \\
\text { incident } \\
\text { on the } \\
\text { photonic } \\
\text { crystal } \\
\text { cannot } \\
\text { propagat } \\
\text { e at } \\
\text { normal } \\
\text { angle }\end{array}$ & $\begin{array}{l}\text { It is used } \\
\text { to get } \\
\text { maximum } \\
\text { reflectivity } \\
\text { around the } \\
\text { target } \\
\text { wavelengt } \\
\text { h of } \\
\text { operation( } \\
1550 \mathrm{~nm})\end{array}$ \\
\hline $\begin{array}{l}\text { Optical } \\
\text { refract } \\
\text { metric } \\
\text { type } \\
\text { biosen } \\
\text { sor }\end{array}$ & $\begin{array}{l}\text { High } \\
\text { accurac } \\
\text { y and } \\
\text { high } \\
\text { resolutio } \\
\text { n can } \\
\text { be } \\
\text { achieve } \\
\text { d }\end{array}$ & $\begin{array}{l}\text { Sensing is } \\
\text { inefficient }\end{array}$ & $\begin{array}{l}\text { In ability } \\
\text { to } \\
\text { provide } \\
\text { quick } \\
\text { feedback }\end{array}$ & $\begin{array}{l}\text { Different } \\
\text { method of } \\
\text { frequency } \\
\text { modulatio } \\
\text { ns of } \\
\text { higher } \\
\text { frequencie } \\
\text { s and } \\
\text { microwave } \\
\text { ranges }\end{array}$ \\
\hline $\begin{array}{l}\text { Match } \\
\text { zehnde } \\
r \\
\text { interfer } \\
\text { ometer }\end{array}$ & $\begin{array}{l}\text { High } \\
\text { sensitivi } \\
\text { ty }\end{array}$ & $\begin{array}{l}\text { It works only } \\
\text { for the laser } \\
\text { light. }\end{array}$ & $\begin{array}{l}\text { The light } \\
\text { beam will } \\
\text { be } \\
\text { decouple } \\
\text { d by the } \\
\text { two arms } \\
\text { and } \\
\text { recouple } \\
\text { d at the } \\
\text { receiver } \\
\text { end }\end{array}$ & $\begin{array}{l}\text { It can be } \\
\text { used as } \\
\text { temperatu } \\
\text { re and } \\
\text { pressure } \\
\text { sensor }\end{array}$ \\
\hline $\begin{array}{l}\text { Optical } \\
\text { fiber } \\
\text { acousti } \\
\mathrm{c} \\
\text { sensin } \\
\mathrm{g} \\
\text { (ofas) }\end{array}$ & $\begin{array}{l}\text { Anti } \\
\text { electro } \\
\text { magneti } \\
\text { c } \\
\text { interfere } \\
\text { nce and } \\
\text { less } \\
\text { loss for } \\
\text { long } \\
\text { distance } \\
\text { transmis } \\
\text { sion }\end{array}$ & $\begin{array}{l}\text { Efficiency is } \\
\text { less }\end{array}$ & $\begin{array}{l}\text { With } \\
\text { different } \\
\text { frequenc } \\
\text { y band } \\
\text { the } \\
\text { detected } \\
\text { acoustic } \\
\text { wave can } \\
\text { be } \\
\text { applicabl } \\
\text { e for } \\
\text { various } \\
\text { field }\end{array}$ & $\begin{array}{l}\text { Due to } \\
\text { there high } \\
\text { sensitivity } \\
\text { compact } \\
\text { size these } \\
\text { sensor are } \\
\text { used in } \\
\text { different } \\
\text { field } \\
\text { application }\end{array}$ \\
\hline $\begin{array}{l}\text { Piezo } \\
\text { electric } \\
\text { sensor } \\
(p z t)\end{array}$ & $\begin{array}{l}\text { Small } \\
\text { size, } \\
\text { light } \\
\text { weight }\end{array}$ & $\begin{array}{l}\text { Piezo } \\
\text { electric } \\
\text { sensor is not } \\
\text { suitable for } \\
\text { use with in a } \\
\text { polymer } \\
\text { bonded } \\
\text { explosive } \\
\text { material, it } \\
\text { can } \\
\text { generate } \\
\text { heat are } \\
\text { spark or shot } \\
\text { circuit during } \\
\text { operation }\end{array}$ & $\begin{array}{l}\text { It is only } \\
\text { commerc } \\
\text { ially } \\
\text { available } \\
\text { acoustic } \\
\text { emission } \\
\text { sensor, } \\
\text { which is } \\
\text { driven by } \\
\text { electricity }\end{array}$ & $\begin{array}{l}\text { It can be } \\
\text { used in } \\
\text { acoustic } \\
\text { sensor }\end{array}$ \\
\hline $\begin{array}{l}\text { Fiber } \\
\text { bragg } \\
\text { grating } \\
\text { sensor }\end{array}$ & $\begin{array}{l}\text { Improve } \\
\text { d } \\
\text { sensitivi } \\
\text { ty, }\end{array}$ & $\begin{array}{l}\text { By inducing } \\
\text { chemical } \\
\text { and } \\
\text { biochemical }\end{array}$ & $\begin{array}{l}\text { It is } \\
\text { complex } \\
\text { to } \\
\text { develop }\end{array}$ & $\begin{array}{l}\text { It is used } \\
\text { for } \\
\text { detection } \\
\text { of acoustic }\end{array}$ \\
\hline
\end{tabular}




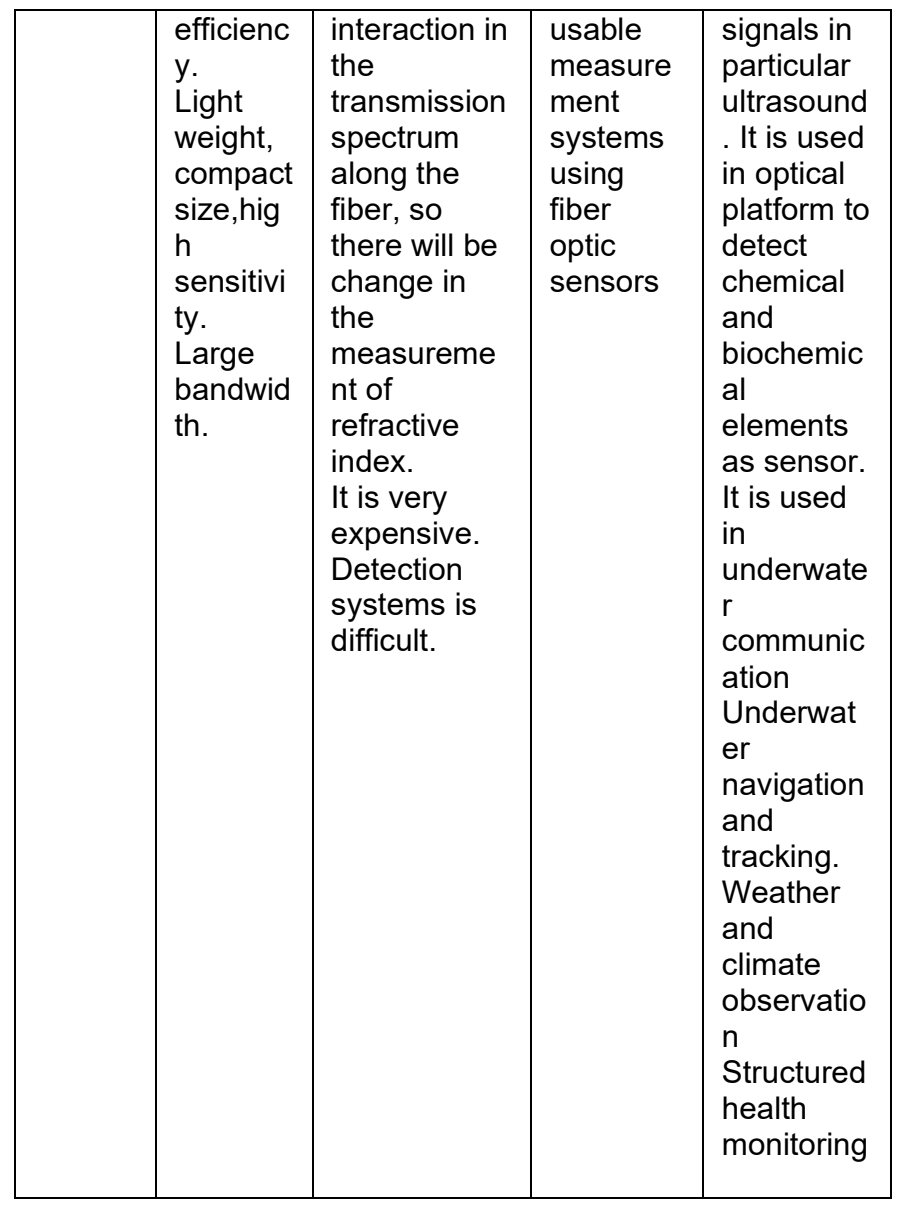

\section{Fundamental Theory Of Fiber Bragg Grating}

A FBG which is a spectrally reflective element and consist of core of an optical fiber. The FBG is consisting of various refractive indices with alternating regions. The difference in refractive indices and as results in Fresnel reflection at each interface which is named as the Bragg wavelength, $\lambda \mathrm{B}$. The wavelength of Bragg is $\lambda_{B}=2 n_{e} \forall$, Where $n_{e}$ the effective refractive index of the grating in the fiber core is and $\forall$ is the grating period.

Strain is applied for measuring the acoustic and ultrasonic signal. If there is change in grating period which means strain is applied and change in refractive index then resultant effect is on strain optic sensor.
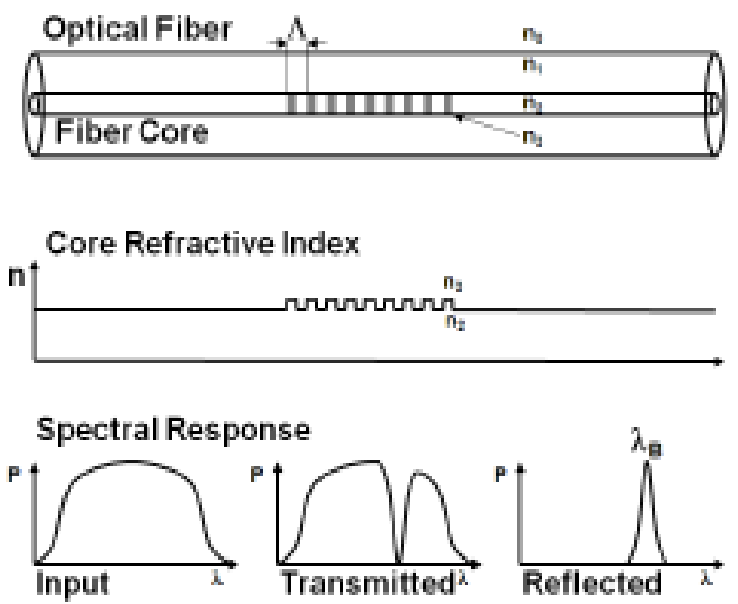

Figure 2. Basic principle operation of Fiber Bragg Grating

The alternative method is to detect the acoustic signal using fiber optic sensor, because this kind of sensors is extremely sensitive. Their size is small and it as oil-well monitoring where space is constraint [9].

For measuring sound in water a hydrophone is simply a device [10-11]. A fiber hydrophone is an acoustic sensor used for sensing the element.

\section{Fiber Bragg Grating Acoustic Emission}

This Sensor is used in various fields. The sensing principle is co-ordination between the $\mathrm{AE}$ wave and the sensor is introduced based on an FBG AE sensor. For FBG sensor, on the surface of the sensor, a thin polymer bonded explosive material is used. In order to improve the accuracy of the sensor the time coefficient Location method is proposed.

There are different applications which come underwater such as oil exploration, underwater pollution examination, and so on. In order to work on the application such as under water wireless sensor grids are involved in such case [12]. Sub aquatic sensor involved to provide sensitization. But there will be problem with wireless sensor network application for sensing. So FBG can diploid for this research work. Much other work is carried out for sensing research work [13]. 


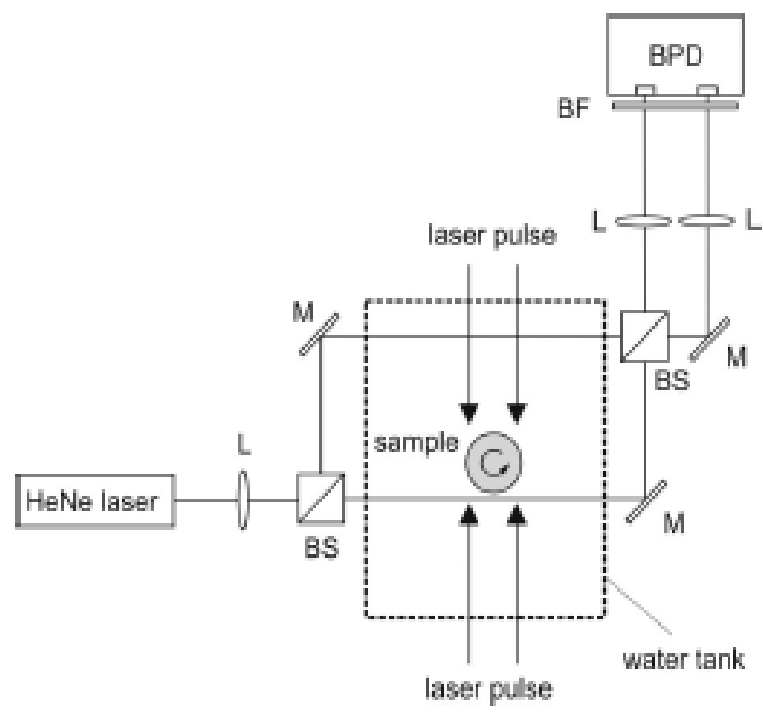

Figure 3. Experimental setup for photo acoustic tomography with Mach Zehnder Interferometer as acoustic line detector.

Researcher's works on another approach to detect the acoustic signal and the method is three-dimensional photo acoustic imaging method. This method uses a MZI sensor for calculation of acoustic waves generated in an object. With short laser pulses. Fig 3 shows that basic working principle of interferometric [27]. Researcher worked on that Interferometer and explained the working principle in detail.

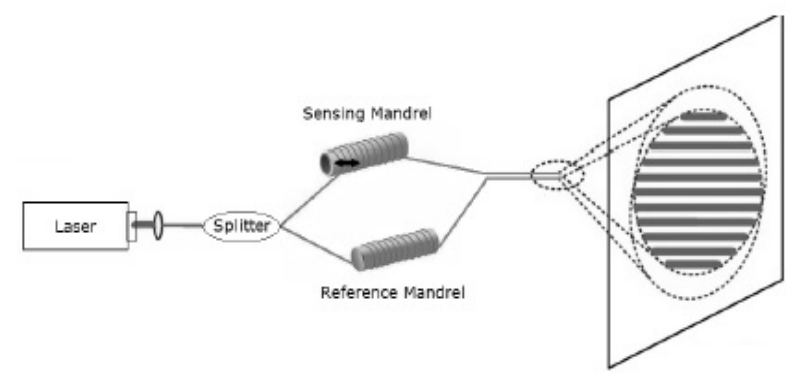

Figure 4. Fiber optical interferometer setup to detect the acoustic signal

Considering conventional solid core fiber and hollow core photonic crystal fiber (HCPCF), higher sensitivity was reported.

Another way to utilize the fiber Bragg Grating sensor is to detect the octane number of gasoline and the presence of organic compounds in biological fuels. Fiber Bragg Grating sensor is using $\pi$ shifted etched. The $\pi$ phase shifted FBGs which as narrow resonance bandwidth dimensions with the size of a grating and a good sensitivity to changes in the refractive index [14]. So this FBG with $\pi$ shifted is used as fuel detection sensor.

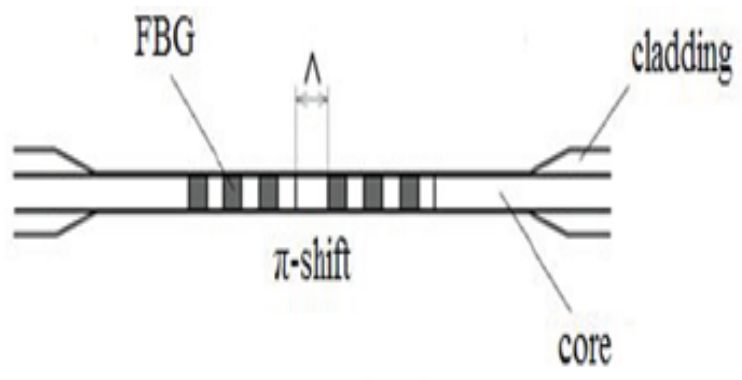

Figure 5. $\pi$ shifted Fiber Bragg Grating

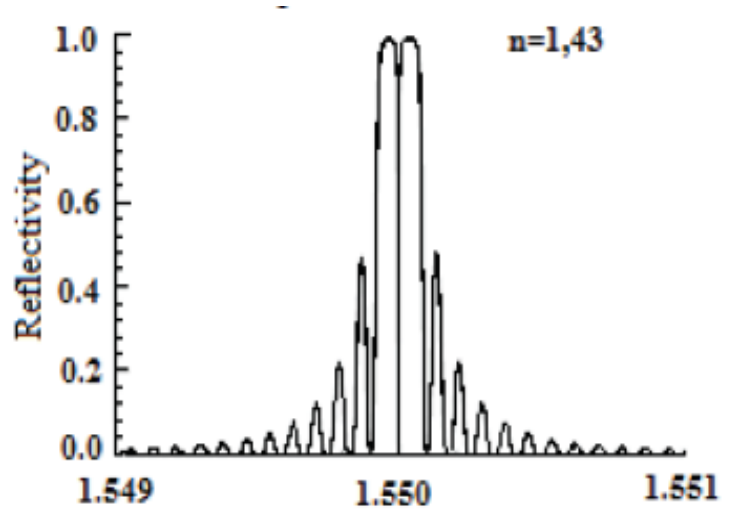

Figure 6. The Special characteristic of $\pi$ shifted of FBG

\section{Interferometric Ultrasound Detector}

The above Fig. 3. Shows the experimental setup of the MZI The continuous laser beam is separated into signal beam and reference beam is incident on an arm of a MZI sensor. Object is placed near to the signal beam and both beams Travers a water tank. To improve the temporal resolution of the sensor, the diameter of the beam near the object is reduced.

The output of the differential amplifier as a function of path length difference is a sine wave [15].

In order to monitor low frequency underwater acoustic signal, the PCF based acoustic sensor was reported by Dnyandeo et al. [16]. 


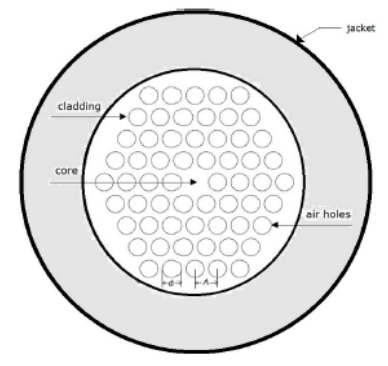

Figure 7. Cross sectional diagram of PCF fiber

\subsection{FBG Construction:}

The construction of FBGs which is able to reflects required wavelengths of light and transmits remaining all others. It depends on Bragg condition which means The Bragg reflected wavelength changes depends on pressure, temperature, strain etc. This physical parameter changes refractive index which in turn affect the reflected wavelength [17-19].

\subsection{PCF-FBG Sensor:}

It is constructed on to the core of the photonic crystal fiber. This sensor has a fiber optic sensor system which is capable of distinguish the effects of physical Parameters [22]. The improved sensor system as power, energy scaling and discrimination of cross-sensitivities with good SNR [20, 21].

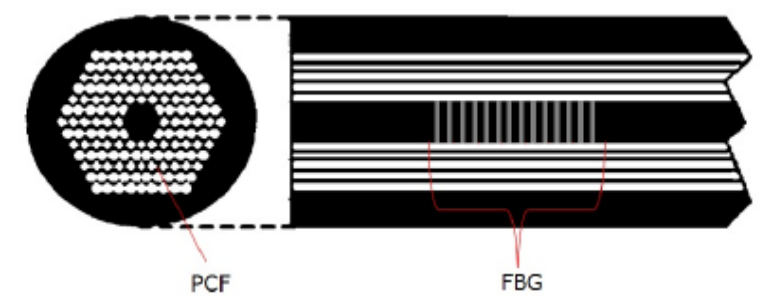

Figure 8. PCF FBG Sensor

There are many advantages for FBG sensor and this sensor is applicable in numerous fields. Based on its advantages and good characteristic FBG sensor can be applicable for detection of acoustic signal.

\section{Temperature Sensing}

Fiber bragg grating can be used as temperature sensor. By changing the temperature of the fiber which can produce a shift in the Bragg wavelength due to thermal expansion and that can change the grating spacing. If there is change in temperature resultant change in index of refraction. For temperature change the fractional Bragg wavelength will be changed $[23,24]$.

The detection of acoustic signal is difficult and very crucial for marine fields. By demonstrating MZI hydrophone using polarization maintaining PCF, operated at $1550 \mathrm{~nm}$ source with these data will be compared.

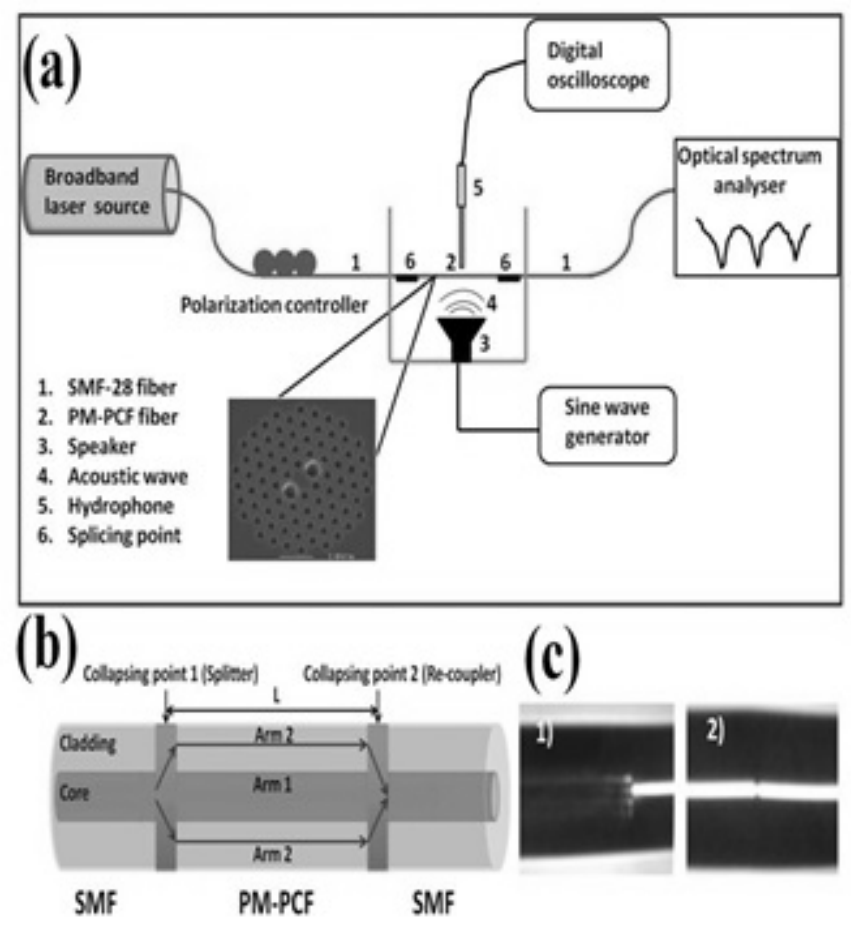

Figure 9. a) Low frequency detection sensor set up b) Mach Zehnder Interferrometer schematic

c) SMF(Single mode fiber ) and HC PCF(holo core photonic bandgap fiber) Spliced region. 

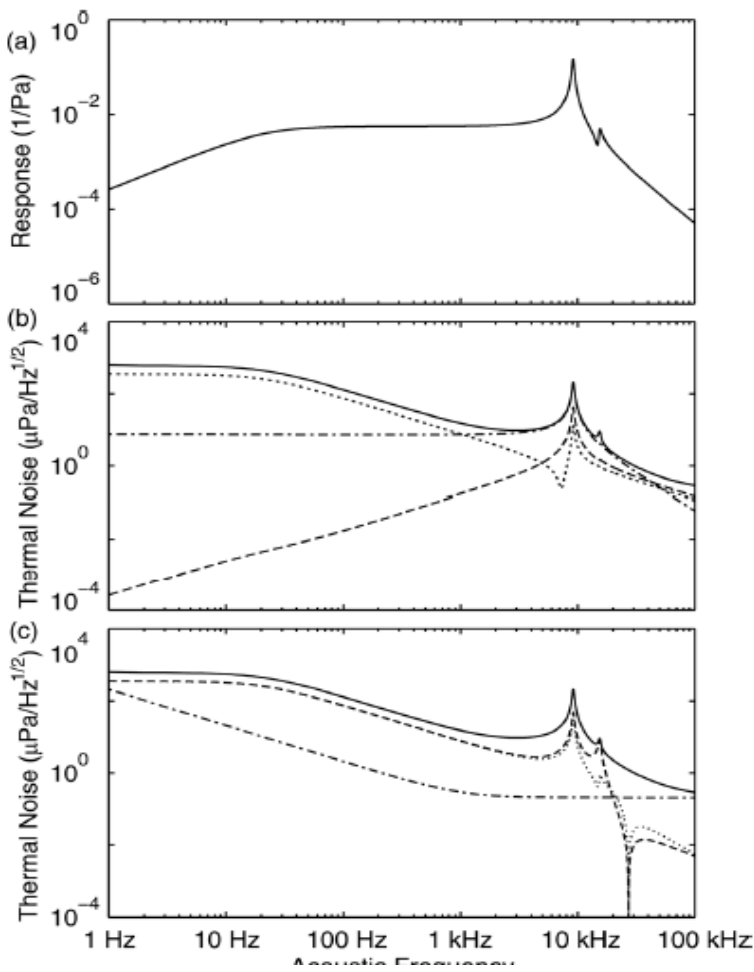

Figure 10. Acoustic Frequency Response

The market of optical sensor is growing very fast and essential. The number of advantages is required for fiber optic technology which is compared with conventional piezoelectric hydrophone techniques $[25,26]$.

\section{Merits and Demerits}

\section{Merits}

- Fiber optic sensor does not have any disturbance from EMI (Electromagnetic Interference) and RFI (Radio Frequency Interference).

- It is safe and suitable to be used in extreme vibration and harse environments.

- It is tolerant against high temperature (i.e. $>1450 \mathrm{oC}$ ) and corrosive environments.

- It offers good sensitivity

- It is less weight and small in size.

- It offers wide dynamic range and large bandwidth.

- It offers multiplexing and remote sensing capabilities.

- It can be used in multifunctional sensing capabilities for mechanical measurement, electric measurements, Magnetic measurements, chemical \& biological sensing.

- It can measure nearly all of the physical measurands.

\section{Demerits}

- It is very expensive.

- Detection system is difficult.

- It is complex to develop usable measurement systems using fiber optic sensors

\section{Conclusion}

The review paper demonstrated the reported work and corresponding results. Observation is done with characteristic of fiber bragg grating sensor with good sensitivity. FBG sensor is applied in different field. The structure and properties of this sensor is described in detail. The knowledge about structure and working principle of FBG sensor and broaden their idea about this sensor and can provide new solution for further exploit the potential of FBG sensor. The technology of FBG and Mach Zehnder based sensor will be controllability and integration and the exploration on new mechanism and new method.

\section{Acknowledgement.}

The authors wish to thanks to the anonymous authors for their valuable comments. Authors wish to thank Dr. Preeta Sharan, R\&D Head, Department of ECE, Oxford college of Engineering, Bangalore for her constant support and timely guidance.

\section{References}

[1] Tao Fu et.al. "Application of Fiber Bragg Grating Acoustic Emission Sensors in Thin Polymer-Bonded Explosives", 13 October 2018; Accepted: 31 October 2018; Published: 5 November 2018, www.mdpi.com/journal/sensors.

[2] Xiaohong Bai et.al. "A Submerged Optical Fiber Ultrasonic Sensor Using Matched Fiber Bragg Gratings", Received: 13 October 2018; Accepted: 31 October 2018; Published: $\quad 5 \quad$ November 2018 www.mdpi.com/journal/sensors.

[3] Shengye HUANG1, Xiaofeng JIN1, Jun ZHANG2, Yi CHEN2, Yuebin WANG2, Zhijun ZHOU1, and Juan NI1, "An Optical Fiber Hydrophone Using Equivalent Phase Shift Fiber Bragg Grating for Underwater Acoustic Measurement" 1Department of Information Science \& Electronic Engineering, Zhejiang University, Hangzhou, 310027, China 2Hangzhou Applied Acoustics Research Institute, Hangzhou, 310014, China Photonic Sensors (2011) Vol. 1, No. 3: 289-294 Received: 27 October 2010 / Revised version: 5 December 2010.

[4] Jincy Johny, Thomas Smith, Kaushalkumar Bhavsar, Radhakrishna Prabhu, "Design of optical fiber based highly sensitive acoustic sensor for underwater applications", 978-1-5090-5278-3/17/\$31.00 C2017 IEEE.

[5] F. Baldini, F. Baldini, "Optical fiber gratings as tools for chemical and biochemical sensing," Analytical and Bioanalytical Chemistry January 2012, Volume 402, Issue 1, pp 109-116, Springer Link.

[6] Alessandro Candiani,a Alessandro Bertucci,b Sara Giannetti,a Maria Konstantaki,c Alex Manicardi,b Stavros 
Pissadakis,c Annamaria Cucinotta,a Roberto Corradini,b and Stefano Selleria, "Label-free DNA biosensor based on a peptide nucleic acid-functionalized microstructured optical fiber-Bragg grating", Journal of Biomedical Optics 18(5), 057004 (May 2013) Vol. 18(5) 057004-1-6.

[7] Sadykov, I.R., Morozov O.G., Sadeev T.S., "The biosensor based on fiber Bragg grating to determine the composition of the fuel and biofuel", Optical Technologies for Telecommunications 2011, edited by Vladimir A. Andreev, Vladimir A. Burdin, Albert H. Sultanov, Oleg G. Morozov, Proc. of SPIE Vol. 8410, 84100F - (C) 2012 SPIE CCC code: $/ 12 / \$ 18$ - doi: 10.1117/12.923174 Proc. of SPIE Vol. 8410 84100F-1.

[8] ] Kavya V. Ullal1, Dr. Preeta Sharan2 Kavya V. Ullal1, Dr. Preeta Sharan2, "Micro Displacement Sensor Design Based on Photonic Crystal Emulating MOEMS for Detection of Acoustic Signals",Department of ECE, The Oxford College of Engineering, VTU, Bangalore, India978-1-4799-8047-5/15/\$31.00_c 2015 IEEE

[9] K.O. Hill, et al., "Photosensitivity in optical fiber waveguides: Application to reflection filter fabrication" Appl. Phys. Lett. 32(10), 647-649 (1978).

[10] F. J et.al , " low intensity acoustic waves detection using an interferometer", Vibro engineering Procedia, Vol. 11, 2017, p 151-154 24 th April 2017.

[11] R. M. Gomathi1 • J. Martin Leo Manickam, "Energy Efficient Shortest Path Routing Protocol for Underwater Acoustic Wireless Sensor Network," Wireless Pers Commun Springer Science, Business media LLc 2017.

[12] Onur Kilic et. al., "Miniature photonic-crystal hydrophone optimized for ocean acoustics," E. L. Ginzton Laboratory, Stanford University, 348 Via Pueblo Mall, Stanford, California 94305 (Received 28 March 2010; revised 8 December 2010; accepted 18 December 2010) PACS number(s): 43.30.Yj, 43.38.Ne, 43.35.Sx [KGF] Pages: $1837-1850$.

[13] Pawar D, Rao CN, Choubey RK, Kale S., “ Mach-Zehnder interferometric photonic crystal fiber for low acoustic frequency detections", Applied Physics Letters. 2016; 108(4):041912.

[14] Hill KO, Meltz G, “ Fiber Bragg grating technology fundamentals and overview", Lightwave Technology, Journal of. 1997; 15(8):1263-1276.

[15] Jincy Johny et.al., "Design of optical fiber based highly sensitive acoustic sensor for underwater applications", 978-1-5090-5278-3/17/\$31.00 C2017 IEEE.

[16] W. W. Morey, "Fiber optic Bragg grating sensors", 98 / SPIE VoL 1169 Fiber Optic and Laser Sensors VII (1989) 12/17/2013 Terms of Use.

[17] Dnyandeo Pawar,et al. "Mach-Zehnder interferometric photonic crystal fiber for low acoustic frequency Detections", Citation: Appl. Phys. Lett. 108, 041912 (2016); doi: 10.1063/1.4940983 Applied Physics Letters 108, 041912 (2016).

[18] M. J. F. Digonnet, B. J. Vakoc, C. W. Hodgson, and G. S. Kono, Proc. SPIE 5502, 39 (2004). J. P. F. Wooler and R. I.wavesJ.-O. Gaudron et.al., "Long Period Grating-based optical fiber sensor for the underwaterdetection of acoustic waves", Sensors and Actuators A 201 (2013) 289- 293 C) 2013 Elsevier B.V. All rights reserved.

[19] Sadykov et.al., "The biosensor based on fiber Bragg grating to determine the composition of the fuel and biofuel", Optical Technologies for Telecommunications 2011, edited by Vladimir A. Andreev, Vladimir A. Burdin, Albert H. Sultanov, Oleg G. Morozov, Proc. of SPIE Vol.
8410, 84100F - (C) 2012 SPIE CCC code: $/ 12 / \$ 18 \cdot$ doi: 10.1117/12.923174 Proc. of SPIE Vol. 8410 84100F-1.

[20] Ming, Li., "Multichannel notch filter based on phaseshifted phase-only-sampled fiber Bragg grating", Optics Express. Papers 16 (23), 19388-19394, (2008).

[21] S.M. Murphy, P.C. Hines, Examining the robustness of automated aural classification of active sonar echoes. J. Acoust. Soc. Am. 135(2), 626-636 (2014).

[22] J O. Gaudron et al., "Long Period Grating-based optical fiber sensor for the underwater detection of acoustic wavesJ", Received in revised form 16 July 2013 Sensors and Actuators A: Physical jo ur nal homepage: www.elsevier.com/locate/sna.

[23] Geoffrey A et.al., "Large-Scale Remotely Interrogated Arrays of Fiber-Optic Interferometric Sensors for Underwater Acoustic Applications", Ieee Sensors Journal, Vol. 3, No. 1, February 2003 1530-437X/03\$17.00 (C) 2003 IEEE.

[24] Muller-Karger, F.E.; Hestir, E.; Ade, C.; Turpie, K.; Roberts, D.A., "Satellite sensor requirements for monitoring Essential biodiversity variables of coastal ecosystems" Ecol. Appl. 2018, 28, 749-760. [CrossRef] [PubMed].

[25] Yamashita, K.; Nishiumi, T.; Arai, K.; Tanaka, H.; Noda,M, " Intrinsic stress control of sol-gel derived PZT films for buckled diaphragm structures of highly sensitive ultrasonic microsensors", Eurosensors 2015, 120, 12051208.

[26] Meng, L.; Yi, J.; Tan, X.; Cai, L. Study on phase shifted fiber Bragg grating spatial sensing properties to ultrasonic wave at arbitrary excitation angle. IEICE Electron. Express 2017, 14.

[27] Guenther Paltauf et.al. Photoacoustic tomography using a Mach-Zehnder interferometer as an acoustic line detector", Received 22 May 2006; revised 14 December 2006; accepted 2 January 2007; posted 2 February 2007 (Doc. ID 71188); published 15 May 2007, OCIS codes: 110.5120, 110.6960, 3352 Applied Optics _ Vol. 46, No. 16 _ 1 June 2007

[28] T.Zouache,A. Hocini, A.Harhouz, R.Mokhtari," Design of pressure sensor based on two dimensional photonic crystal",ACTA PHYSICA POLONICA A, No1, Vol 131, PP68-70, 2017. 